\begin{tabular}{|l|l|l||}
\hline \multicolumn{2}{|c|}{ PublisherInfo } \\
\hline \hline PublisherName & $:$ & BioMed Central \\
\hline \hline PublisherLocation & $:$ & London \\
\hline \hline PublisherImprintName & $:$ & BioMed Central \\
\hline \hline
\end{tabular}

\title{
End-joining in yeast
}

\begin{tabular}{|l|l|l||}
\hline \multicolumn{2}{|c|}{ ArticleInfo } \\
\hline \hline ArticleID & $:$ & 4271 \\
\hline \hline ArticleDOI & $:$ & $10.1186 /$ gb-spotlight-20011206-01 \\
\hline \hline ArticleCitationID & $:$ & spotlight-20011206-01 \\
\hline \hline ArticleSequenceNumber & $:$ & 342 \\
\hline \hline ArticleCategory & $:$ & Research news \\
\hline \hline ArticleFirstPage & $:$ & 1 \\
\hline \hline ArticleLastPage & $:$ & 2 \\
\hline \hline & & RegistrationDate : 2001-12-06 \\
ArticleHistory & $:$ & OnlineDate \\
\hline \hline ArticleCopyright & $:$ & BioMed Central Ltd2001 \\
\hline \hline ArticleGrants & $:$ & \\
\hline \hline ArticleContext & $:$ & 130592211 \\
\hline \hline
\end{tabular}




\section{Jonathan B Weitzman}

Email: jonathanweitzman@hotmail.com

The DNA-repair mechanism referred to as non-homologous end-joining (NHEJ) involves the Ku proteins (Ku70 and Ku80), DNA ligase IV and Lif1/XRCC4. Meiotic cells down-regulate NHEJ, to favour homologous recombination. In the December 6 Nature, Maria Valencia and colleagues describe a mechanism for the down-regulation of NHEJ in meiosis-competent MAT a /MATa diploid Saccharomyces cerevisiae cells (Nature 2001, 414:666-669). They found that LIFI (encoding ligaseinterfacing factor 1) expression was decreased in the diploid strain, but LIF1 overexpression only partially restored NHEJ. Microarray analysis of mating-type mutant strains led them to identify a novel gene, $N E J 1$ (non-homologous end-joining defective). Deletion of NEJI reduces NHEJ, and the gene is strongly mating-type-regulated. The promoter regions of both the LIF1 and NEJ1 genes contain binding sites for the Mata1-Mat $\alpha 2$ repressor. Valencia et al.suggest that NEJ1 affects the cellular localization of LIF1 during meoisis. It will be interesting to see whether similar regulation of NHEJ components occurs during meiosis in mammalian cells.

\section{References}

1. DNA breakage and repair.

2. Nature, [http://www.nature.com] 